\title{
Contrasting watershed-scale trends in runoff and sediment yield complicate rangeland water resources planning
}

\author{
Matthew D. Berg ${ }^{1, a}$, Franco Marcantonio ${ }^{2}$, Mead A. Allison ${ }^{3,4}$, Jason McAlister ${ }^{5}$, Bradford P. Wilcox ${ }^{1}$, and \\ William E. Fox ${ }^{1,5}$ \\ ${ }^{1}$ Department of Ecosystem Science and Management, Texas A\&M University, College Station, Texas, USA \\ ${ }^{2}$ Department of Geology and Geophysics, Texas A\&M University, College Station, Texas, USA \\ ${ }^{3}$ The Water Institute of the Gulf, Baton Rouge, Louisiana, USA \\ ${ }^{4}$ Tulane University, Department of Earth and Environmental Sciences, New Orleans, Louisiana, USA \\ ${ }^{5}$ Texas A\&M AgriLife Blackland Research \& Extension Center, Temple, Texas, USA \\ ${ }^{a}$ now at: Save Water Co, Houston, Texas, USA \\ Correspondence to: Matthew D. Berg (mbergtamu@gmail.com)
}

Received: 16 December 2015 - Published in Hydrol. Earth Syst. Sci. Discuss.: 18 January 2016

Revised: 18 May 2016 - Accepted: 20 May 2016 - Published: 15 June 2016

\begin{abstract}
Rangelands cover a large portion of the earth's land surface and are undergoing dramatic landscape changes. At the same time, these ecosystems face increasing expectations to meet growing water supply needs. To address major gaps in our understanding of rangeland hydrologic function, we investigated historical watershed-scale runoff and sediment yield in a dynamic landscape in central Texas, USA. We quantified the relationship between precipitation and runoff and analyzed reservoir sediment cores dated using cesium137 and lead-210 radioisotopes. Local rainfall and streamflow showed no directional trend over a period of 85 years, resulting in a rainfall-runoff ratio that has been resilient to watershed changes. Reservoir sedimentation rates generally were higher before 1963, but have been much lower and very stable since that time. Our findings suggest that (1) rangeland water yields may be stable over long periods despite dramatic landscape changes while (2) these same landscape changes influence sediment yields that impact downstream reservoir storage. Relying on rangelands to meet water needs demands an understanding of how these dynamic landscapes function and a quantification of the physical processes at work.
\end{abstract}

\section{Introduction}

Diverse rangeland ecosystems falling along a grasslandforest continuum cover roughly half of the earth's land sur- face (Breshears, 2006). Generally precipitation-limited, they are typically used for livestock grazing and harvesting of woody products rather than crop production. But rangelands worldwide face numerous challenges, including (1) conversion to urban development or cultivation; (2) shifting plant cover, such as encroachment by woody plants and invasion by non-native species; and (3) demands for increased production without sacrificing sustainability (Tilman et al., 2002; Van Auken, 2000; Wilcox et al., 2012b).

As growing populations look to these dynamic landscapes to provide critical ecosystem services - including water supply and water storage - their ability to keep pace with these demands is uncertain (Havstad et al., 2007; Jackson et al., 2001). Some of this uncertainty is due to the tremendous variability of runoff and erosion through time and space, which can vary by orders of magnitude even between portions of a single small field (Gaspar et al., 2013; Ritchie et al., 2005). Landscape changes affect these processes further still, and water and sediment yields depend on interactions between climate, vegetation, and local geology. These complex interactions make predictions difficult, and the influence of human activity adds yet another compounding layer of difficulty (Peel, 2009; Boardman, 2006; Vorosmarty and Sahagian, 2000). As a result, major gaps remain in our understanding of rangeland ecosystems. Further interdisciplinary study is imperative to develop a coherent picture of the link- 
ages between hydrological, ecological, and geological processes (Newman, 2006; Wilcox and Thurow, 2006).

Some rangeland investigations have focused on the potential of these landscapes to provide augmented water yields or storage in small reservoirs. Economic and modeling studies have identified vegetation management as a possible means of increasing runoff and streamflow (Griffin and McCarl, 1989; Afinowicz et al., 2005), and government agencies have incorporated these goals into their programs (Texas State Soil and Water Conservation Board, 2005; USDA-NRCS, 2006). Other concerns center on sediment yield, which threatens downstream surface water storage (Bennett et al., 2002; Dunbar et al., 2010). To determine how to respond to these issues and whether related investments are worthwhile, we must gain a better understanding of how rangeland systems function with respect to water resources.

To date, most research has been based on extrapolation of findings from relatively small-scale studies to larger scales or on modeled results. However, because runoff and sediment production are scale-dependent processes, such extrapolation is often unreliable (de Vente and Poesen, 2005; Wilcox et al., 2003). Since they more accurately reveal the true water and sediment yields of watersheds, studies of these processes conducted at the catchment scale are much more relevant to water planning efforts. But whereas catchment-scale data on precipitation and streamflow are somewhat widely available, corresponding sediment data are lacking. Since they serve as archives of historical watershed conditions, the use of reservoir sediments provides one means of filling this data gap and of investigating the impact of human activity (Edwards and Whittington, 2001; Winter et al., 2001). Linking the findings of such investigations with observed changes at the watershed scale will greatly facilitate the development of effective strategies for managing rangeland water resources.

In this study, we investigated the hydrological and sediment transport dynamics of rangeland watersheds. Our main objectives were to (1) quantify long-term trends in precipitation and streamflow using historical data, (2) estimate historical sedimentation rates through radioisotope analysis of reservoir sediment cores, and (3) explore the potential effects of drought conditions on sediment production with historical data. Addressing these objectives not only improves our understanding of rangeland processes but also provides much needed information on the potential of these landscapes to provide for growing global water needs.

\section{Methods}

\subsection{Study area}

As part of a broader study of landscape change and ecosystem function, we examined rangeland processes in the Lampasas Cut Plain of central Texas, USA. This savanna landscape is characterized by low buttes and mesas separated by broad, flat valleys. Local prevailing geology is Cretaceous limestone; soils are loamy and clayey, with occasional sandy loams, and are susceptible to sheet and gully erosion (Allison, 1991; Clower, 1980). The area is drained by the Lampasas River. Streamflow in the upper reaches of the river is runoff dominated, with localized contributions from spring flow (Prcin et al., 2013), and has been recorded at two primary stations (Fig. 1). Annual precipitation averages approximately $800 \mathrm{~mm}$, decreasing to the north and west (Fig. 2). Winter mean temperature is around $7{ }^{\circ} \mathrm{C}$ and in summer $27^{\circ} \mathrm{C}$.

For the sediment study, we examined eight flood-control reservoirs and their watersheds within the Lampasas River basin. Reservoirs L1, L2, L3, L4, L9, and LX are located in Lampasas County and were constructed between 1958 and 1961. Before impoundment, the parallel watersheds of L1, $\mathrm{L} 2$, and L3, contributed to the downstream watershed of LX. Reservoirs M1 and M4, in Mills County, were completed in 1974. Basic attributes of the reservoirs and their watersheds are compiled in Table 1.

Current local land use is predominantly rangeland, and livestock numbers have fluctuated over the last several decades (Fig. 3a) while remaining among the highest in the region (Wilcox et al., 2012a). Cropland was widespread early in the 20th century (Fig. 3b) but had declined by nearly $80 \%$ by 2012 (Berg et al., 2016). Amid this shifting land use, the area has been characterized by large fluctuations in the extent of woody plant cover, due to brush management and regrowth (Fig. 3c), and a dramatic increase in the density of farm ponds (Fig. 3d) over the last several decades (Berg et al., 2015a).

\subsection{Rainfall and runoff trends}

To investigate local hydrological trends, we analyzed historical precipitation and streamflow data for the Lampasas River basin. We created a composite record of annual precipitation using a Thiessen polygon approach, centering polygons on available National Weather Service (NWS) stations (Fig. 2). Daily streamflow data were derived from the two USGS (US Geological Survey) stream gage stations downstream from the study watersheds. The lower Youngsport station, with a drainage area of $3212 \mathrm{~km}^{2}$, operated between 1924 and 1980; the Kempner station, with a drainage area of $2119 \mathrm{~km}^{2}$ has remained active from 1963 to the present.

We performed an automated base-flow separation of streamflow data from each station (Arnold and Allen, 1999). This digital filter approach is objective and reproducible and partitions annual base flow and storm flow with high efficiency (Arnold et al., 1995) - enabling these components to be interpreted in light of changing landscape conditions.

Using the precipitation (1924-2010) and two streamflow data sets (1924-1980; 1963-2010), we applied a nonparametric Mann-Kendall trend test (Lettenmaier et al., 1994) to detect directional changes in precipitation, total 


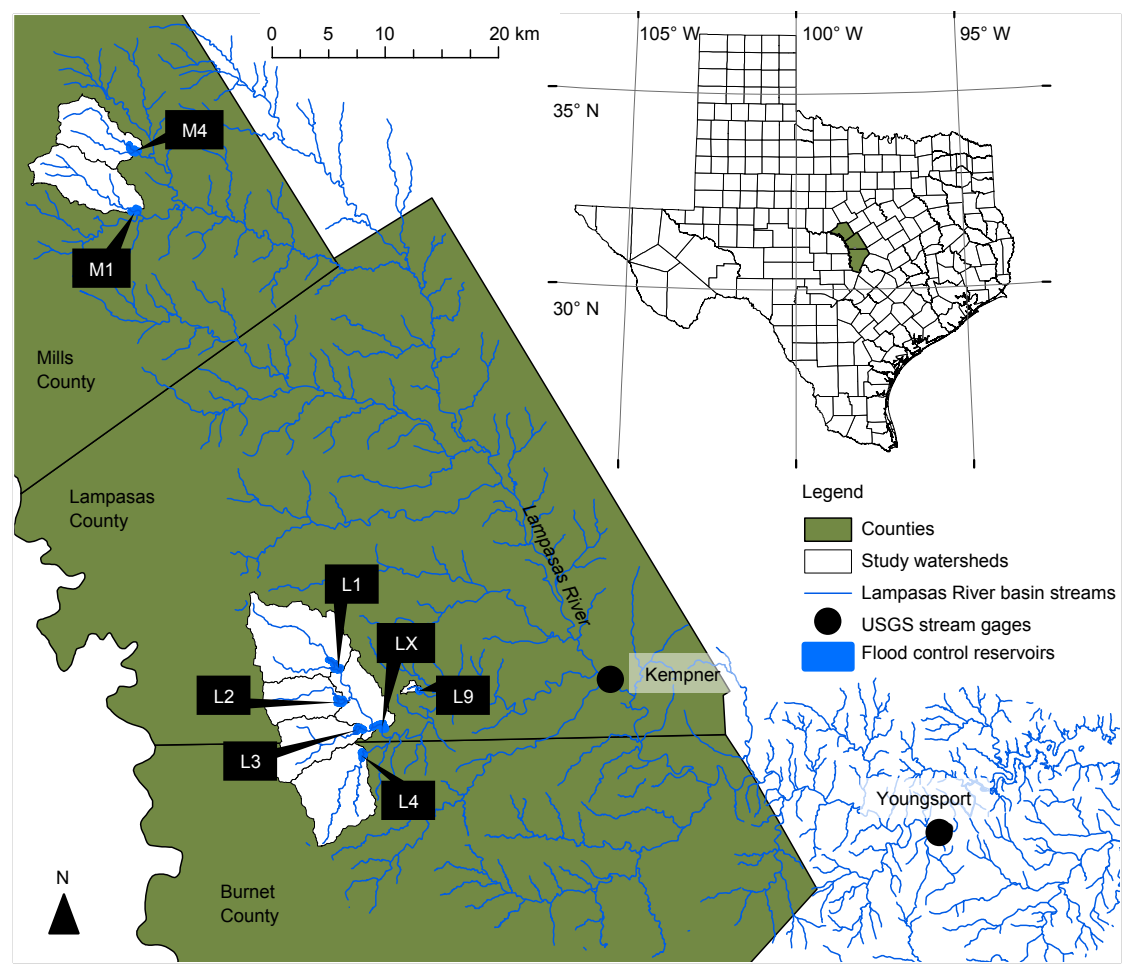

Figure 1. Study area in Texas, USA. Each study watershed encloses a flood-control reservoir from which sediment cores were collected. All watersheds contribute flow to the Lampasas River.

Table 1. Sediment study reservoirs and watershed characteristics.

\begin{tabular}{llllllll}
\hline Reservoir & $\begin{array}{l}\text { Primary } \\
\text { inflow }\end{array}$ & $\begin{array}{l}\text { Surface area } \\
\left(\mathrm{km}^{2}\right)\end{array}$ & $\begin{array}{l}\text { Watershed area } \\
\left(\mathrm{km}^{2}\right)\end{array}$ & $\begin{array}{l}\text { Year } \\
\text { impounded }\end{array}$ & $\begin{array}{l}\text { Year } \\
\text { cored }\end{array}$ & $\begin{array}{l}\text { Min. elev. } \\
(\mathrm{m})\end{array}$ & $\begin{array}{l}\text { Max. elev. } \\
(\mathrm{m})\end{array}$ \\
\hline L1 & Donalson Creek & 0.20 & 50.9 & 1959 & 2010 & 367 & 500 \\
L2 & Pitt Creek & 0.18 & 23.2 & 1959 & 2010 & 362 & 458 \\
L3 & Espy Branch & 0.11 & 27.5 & 1958 & 2010 & 355 & 459 \\
L4 & Pillar Bluff Creek & 0.07 & 41.2 & 1960 & 2012 & 345 & 467 \\
L9 & Cemetery Creek & 0.02 & 1.2 & 1960 & 2012 & 322 & 363 \\
LX & Bean Creek & 0.20 & 23.1 & 1961 & 2012 & 338 & 420 \\
M1 & Middle Bennett Creek & 0.14 & 34.6 & 1974 & 2012 & 422 & 536 \\
M4 & Mustang Creek & 0.15 & 28.0 & 1974 & 2012 & 432 & 534 \\
\hline
\end{tabular}

streamflow, base flow, and storm flow. We performed twotailed statistical tests for significance, with $\alpha=0.10$.

\subsection{Reservoir sedimentation rates}

To shed light on sediment transport processes, we extracted cores from each of the eight reservoirs and analyzed sediments using cesium-137 $\left({ }^{137} \mathrm{Cs}\right)$ and lead-210 $\left({ }^{210} \mathrm{~Pb}\right)$ tracers. ${ }^{137} \mathrm{Cs}$ is present in the environment as a result of atomic weapons testing and accidental emissions. ${ }^{210} \mathrm{~Pb}$ occurs naturally. Both can be used to estimate sedimentation rates and interpret transport history in a variety of environments (Walling et al., 2003; Ritchie and McHenry, 1990; Appleby and Oldfield, 1978). Coring sites were selected by locating the thickest sediment deposits through exploratory hydroacoustic surveys (US Army Corps of Engineers, 1989, 2013; Dunbar et al., 2002). In each reservoir, we extracted sediment cores at identified sites near the dam structure, from locations corresponding to the pre-impoundment floodplain (Fig. 4). Taking cores from these areas reduces the likelihood of capturing mixed profiles, which skew analysis (SanchezCabeza and Ruiz-Fernández, 2012). It also ensures the collection of fine sediments, to which the radioisotopes preferentially adsorb (Bennett et al., 2002). We extracted cores using a portable vibracoring system suspended from a floating platform. This method captures unconsolidated, saturated sediments with minimal disturbance and compaction 
Table 2. Linear sedimentation rates derived from radioisotope activities.

\begin{tabular}{|c|c|c|c|c|c|c|c|}
\hline \multirow{3}{*}{ Core } & \multicolumn{4}{|c|}{${ }^{137} \mathrm{Cs}$} & \multicolumn{3}{|c|}{${ }^{210} \mathrm{~Pb}$} \\
\hline & \multicolumn{2}{|c|}{ Pre-1963 } & \multicolumn{2}{|c|}{ Post-1963 } & \multicolumn{2}{|c|}{ Core mean } & \multirow{2}{*}{$\begin{array}{l}R^{2} \\
\ln \text { dpm g } \\
\text { vs. depth }\end{array}$} \\
\hline & $\mathrm{cm} \mathrm{yr}^{-1}$ & $\mathrm{~cm} \mathrm{yr}^{-1} \mathrm{~km}^{-2}$ & $\mathrm{~cm} \mathrm{yr}^{-}$ & $\mathrm{cm} \mathrm{yr}^{-1} \mathrm{~km}^{-2}$ & $\mathrm{~cm} \mathrm{yr}^{-1}$ & $\mathrm{~cm} \mathrm{yr}^{-1} \mathrm{~km}^{-2}$ & \\
\hline L1 & 6.4 & 0.13 & 2.9 & 0.06 & 3.1 & 0.06 & 0.90 \\
\hline L2 & 3.4 & 0.15 & 0.8 & 0.03 & 0.9 & 0.04 & 0.97 \\
\hline L3 & 1.4 & 0.05 & 2.1 & 0.08 & 1.3 & 0.04 & 0.96 \\
\hline L4 & a & $\mathrm{a}$ & $0.5^{\mathrm{b}}$ & $0.01^{\mathrm{b}}$ & 1.2 & 0.03 & 0.93 \\
\hline L9 & 2.5 & 2.02 & 0.4 & 0.32 & 0.4 & 0.19 & 0.94 \\
\hline LX & $\mathrm{a}$ & $\mathrm{a}$ & 0.1 & $<0.01$ & $\mathrm{c}$ & $\mathrm{c}$ & $\mathrm{c}$ \\
\hline M1 & $\mathrm{a}$ & $\mathrm{a}$ & 1.5 & 0.04 & $\mathrm{c}$ & $\mathrm{c}$ & $\mathrm{c}$ \\
\hline M4 & a & a & $0.4^{\mathrm{b}}$ & $0.01^{\mathrm{b}}$ & 0.8 & 0.01 & 1.00 \\
\hline
\end{tabular}

${ }^{\text {a }}$ Core did not display a ${ }^{137} \mathrm{Cs}$ peak, and rates were calculated using the time elapsed since impoundment.

${ }^{b}$ Core did not capture the pre-impoundment surface and likely underestimates true values.

${ }^{c}$ Core showed significant vertical mixing, preventing calculation of sedimentation rate.

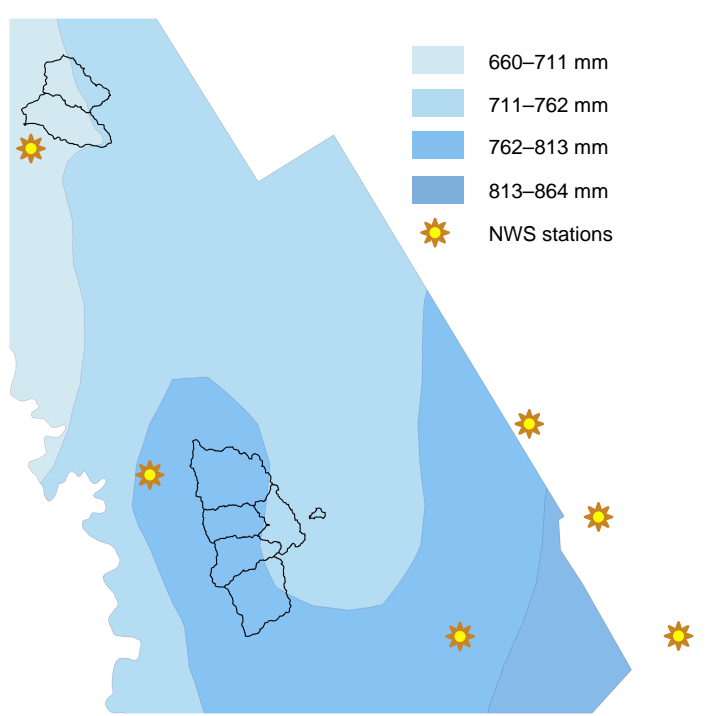

Figure 2. Average annual precipitation gradient and location of National Weather Service (NWS) stations used to construct historical precipitation record.

(Lanesky et al., 1979). The cores were collected with an aluminum pipe lowered to the point of refusal, penetrating the pre-impoundment surface. Retrieved cores were sealed and transported upright to cold storage $\left(\sim 5^{\circ} \mathrm{C}\right)$.

We sectioned each core vertically in $3 \mathrm{~cm}$ intervals, drying each section for analysis according to IAEA (2003) protocols. A subsample of each core section was ground to homogenize its contents, sealed in a $50 \mathrm{~mm} \times 9 \mathrm{~mm}$ Petri dish, and allowed to ingrow for at least 21 days so that ${ }^{210} \mathrm{~Pb}$ supported levels reached equilibrium. Counts for ${ }^{210} \mathrm{~Pb}$ and ${ }^{137} \mathrm{Cs}$ were performed according to Hanna et al. (2014) using a Canberra low-energy germanium gamma spectrometer. Radioisotope activity was indicated by photopeaks at $46 \mathrm{keV}$ (total ${ }^{210} \mathrm{~Pb}$ ) and $661.6 \mathrm{keV}\left({ }^{137} \mathrm{Cs}\right)$. Excess ${ }^{210} \mathrm{~Pb}$ was calculated by subtracting the supported activity of the ${ }^{226} \mathrm{Ra}$ parent - obtained by averaging the 295, 351.9, and $609.3 \mathrm{keV}$ peaks of the ${ }^{214} \mathrm{~Pb}$ and ${ }^{214} \mathrm{Bi}$ daughter products - from total measured ${ }^{210} \mathrm{~Pb}$ activity at the $46 \mathrm{keV}$ peak. Activity measurements were validated with IAEA-300 standard reference material.

To determine historical linear sedimentation rates, we used as a chronological marker the depth of peak ${ }^{137} \mathrm{Cs}$ activity (corresponding to the 1963 peak in global atmospheric fallout) (Ritchie et al., 1973). We calculated average linear sedimentation rates for the post-1963 period by dividing this depth by the time elapsed between 1963 and the coring date for each reservoir; we calculated the pre-1963 rates by dividing the depth of sediment below the activity peak by the time elapsed between reservoir impoundment and 1963.

To complement ${ }^{137} \mathrm{Cs}$ analysis, we used excess ${ }^{210} \mathrm{~Pb}$ activities to calculate the linear sedimentation rate for each core (Krishnaswamy et al., 1971; Bierman et al., 1998). We also searched for changing deposition rates within each core, as plots of the natural $\log$ of excess ${ }^{210} \mathrm{~Pb}$ versus depth indicate stable sedimentation rates over time when $R^{2}$ approaches 1.0.

Finally, we obtained historical annual Palmer Modified Drought Index (PMDI) data for the region to identify potential climatic drivers of sedimentation during different periods. We plotted PMDI and annual peak flows (from USGS data) between 1924 and 2010, identifying episodes conducive to increased sediment production (in particular, a wet year or years following a period of intense drought). 


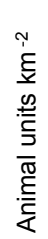

产
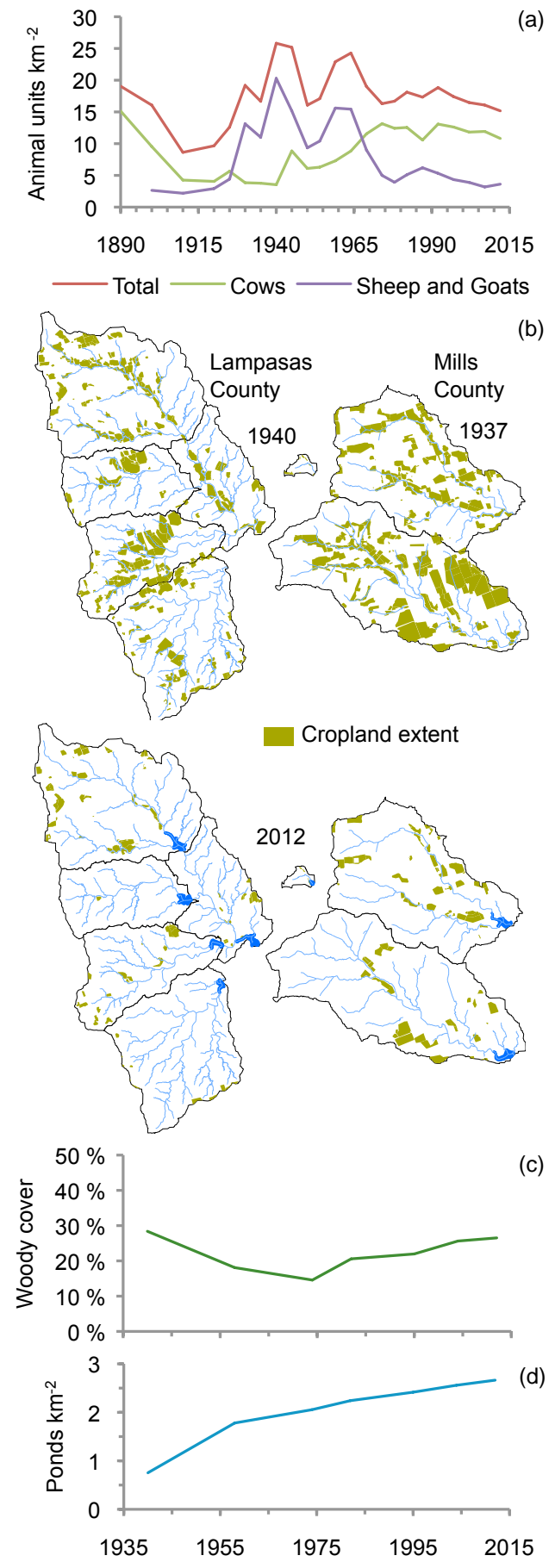

Figure 3. Historical landscape changes in the study area. (a) Livestock numbers in the Lampasas Cut Plain. Recreated from Wilcox et al. (2012a). (b) Extent of active cropland in 1937-1940 and 2012 (Berg et al., 2016). (c) Historical extent of woody plant cover in the study watersheds (Berg et al., 2015b). (d) Pond density over time in the study watersheds (Berg et al., 2015a).

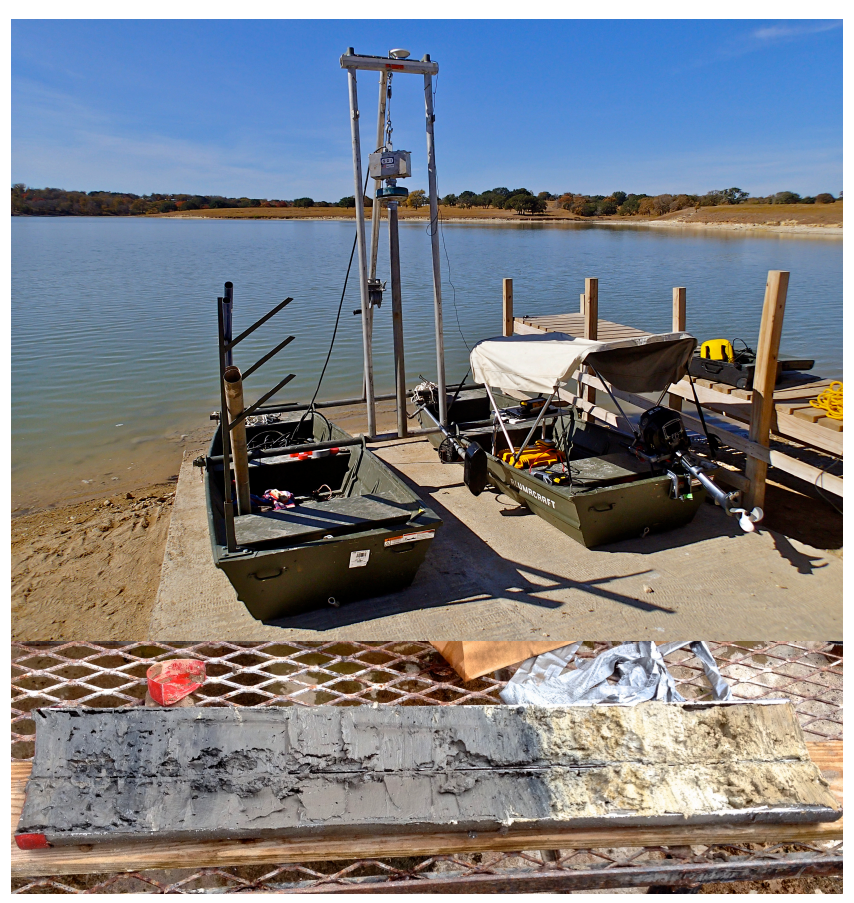

Figure 4. Reservoir sediment coring apparatus (top) and representative sediment profile (bottom).

\section{Results}

\subsection{Rainfall and runoff trends}

Despite a great deal of interannual variability, there was no directional change in local precipitation in 1924-1980 $(p=0.90)$ or $1963-2010(p=0.22)$, which has remained near a long-term average of $800 \mathrm{~mm}$ (Fig. 5a). The same is true of total streamflow (1924-1980: $p=0.98$; 19632010: $p=0.34$ ), which has averaged between 60 and $70 \mathrm{~mm}$ (Fig. 5b). As a result, the rainfall-runoff ratio, the proportion of rainfall leaving a watershed as streamflow, also remained unchanged, at approximately $8 \%$ (1924-1980: $p=0.90,1963-2010: p=0.45$ ). Moreover, neither base flow nor storm flow exhibited a directional change over either period of record. However, base flow as a proportion of total streamflow did increase 1924-1980 $(p=0.02)$ despite minimal change in overall flow - almost doubling its contribution (Fig. 5c).

\subsection{Reservoir sedimentation rates}

Sediment core profiles varied widely in depth between reservoirs - from less than $3 \mathrm{~cm}$ in LX to $162 \mathrm{~cm}$ in L1 (Fig. 6). Activity peaks of ${ }^{137} \mathrm{Cs}$ supported the analysis of pre-1963 sedimentation rates for reservoirs L1, L2, L3, and L9. Overall, linear sedimentation rates were higher before 1963 (Table 2; Fig. 7). Except in the case of L3, sediment deposition has slowed since 1963 - by $54 \%$ in L1, $76 \%$ in L2, and 

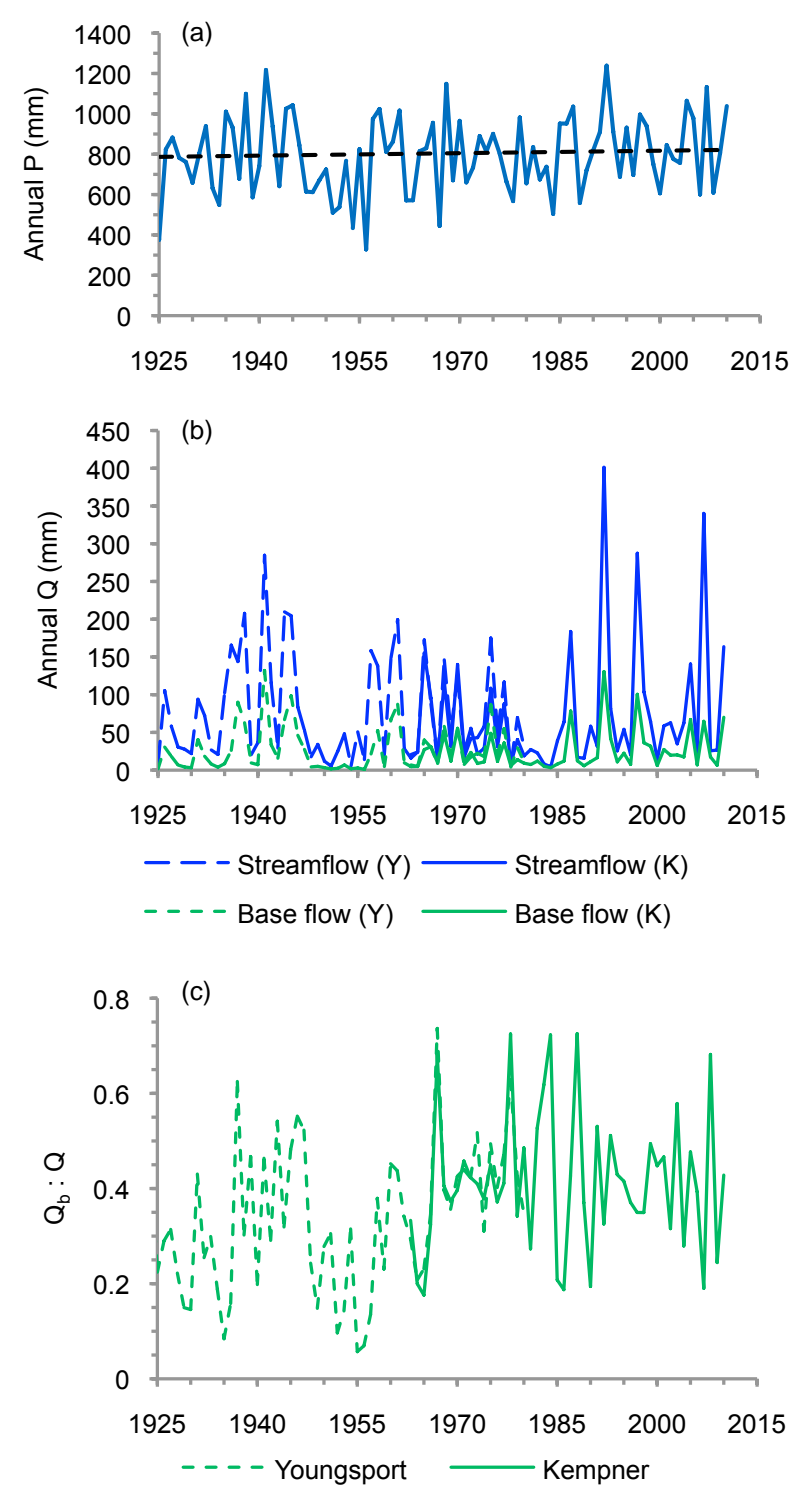

Figure 5. Precipitation and streamflow trends of the Lampasas River basin. (a) Precipitation showed no directional trend. (b) Streamflow showed no directional trend at either the Youngsport (Y) or Kempner (K) station, despite being highly variable. (c) Base flow as a proportion of total streamflow displayed an upward trend over the first portion of the study period.

$84 \%$ in L9. In reservoir L3, it increased by $49 \%$ after 1963. Reservoir L1 exhibited the highest sedimentation rate both before and after 1963 . However, when normalized by catchment area, sedimentation rates varied much more widely. The rates in L9 were by far the highest - surpassing the next highest reservoir by nearly $1400 \%$ for the pre- 1963 period and by $423 \%$ for the post-1963 period.

Cores from L4, LX, M1, and M4 did not display a ${ }^{137} \mathrm{Cs}$ peak. For these cores, sedimentation was assumed to be post1963 and was estimated by dividing sediment depth by time since impoundment. For cores L4 and M4, which did not capture the entire sediment profile, actual rates are likely higher than those calculated.

Cores from reservoirs LX and M1 showed vertical mixing that prohibited ${ }^{210} \mathrm{~Pb}$ analysis. However, remaining cores displayed high correlation between ${ }^{210} \mathrm{~Pb}$ activities and depth, indicating that linear sedimentation rates have remained quite stable over time (Table 2). ${ }^{210} \mathrm{~Pb}$-based estimates generally resembled those based on ${ }^{137} \mathrm{Cs}$ activities. In addition, rates calculated from ${ }^{210} \mathrm{~Pb}$ activities were similar to the post-1963 rates based on ${ }^{137} \mathrm{Cs}$ activities $(p=0.84)$, suggesting good agreement between the two methods for the period since 1963.

Chronological data revealed periods of drought of varying intensity and occasional years of very high streamflow (Fig. 8). The historic 1950s drought was longer and more severe than any other over the last century; it was followed by periods of very high flow in 1957 and 1960. Comparable high flows in 1965 occurred in the middle of a multi-year drought, and the severe drought beginning in 2006 featured occasional elevated peak flows. In 1992, very high flows occurred during a prolonged wet period.

\section{Discussion}

\subsection{Rainfall and runoff trends}

Given the varying trends in precipitation and streamflow observed in many regions (Lins and Slack, 1999; Andreadis and Lettenmaier, 2006), the dynamic hydrological stability in our study area is surprising. At the same time, such consistency sheds light on the effects of watershed changes on local water budgets. Studies at small spatial scales frequently indicate that landscape changes have important water resource impacts, with the specific response depending on the relative importance of evapotranspiration, recharge, and runoff (Foley et al., 2005; Kim and Jackson, 2012). Such changes affect local water budgets and influence water yields (Petersen and Stringham, 2008; Huxman et al., 2005; Farley et al., 2005). However, complicated feedbacks make effects at larger scales highly uncertain and often overwhelmed by climatic and physical characteristics (Peel, 2009; Wilcox et al., 2006; Kuhn et al., 2007). Our rainfall-runoff ratio of $8 \%$ is essentially identical to early estimates of $7 \%$ for the area (Tanner, 1937). The lack of a directional trend in streamflows suggests that this region, like many semiarid landscapes dominated by surface runoff, is largely hydrologically insensitive to shifting watershed characteristics (Wilcox, 2002). Perceived impacts due to changing rooting depths, longer growing seasons for evergreen woody plant species, and assumptions of very high shrub transpiration capacities are not borne out. Changes in land use and land cover - and even the impoundment of small reservoirs - have had negligible impacts on streamflow. These results confirm and add new 

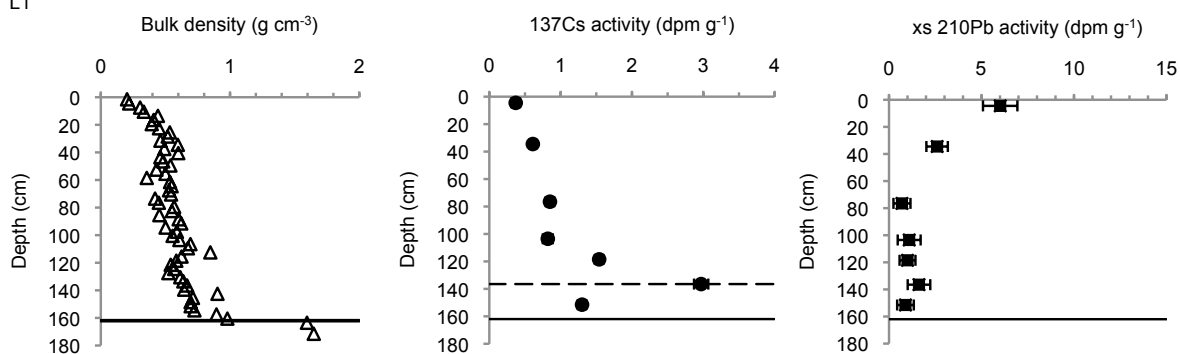

Bulk density $\left(\mathrm{g} \mathrm{cm}^{-3}\right)$
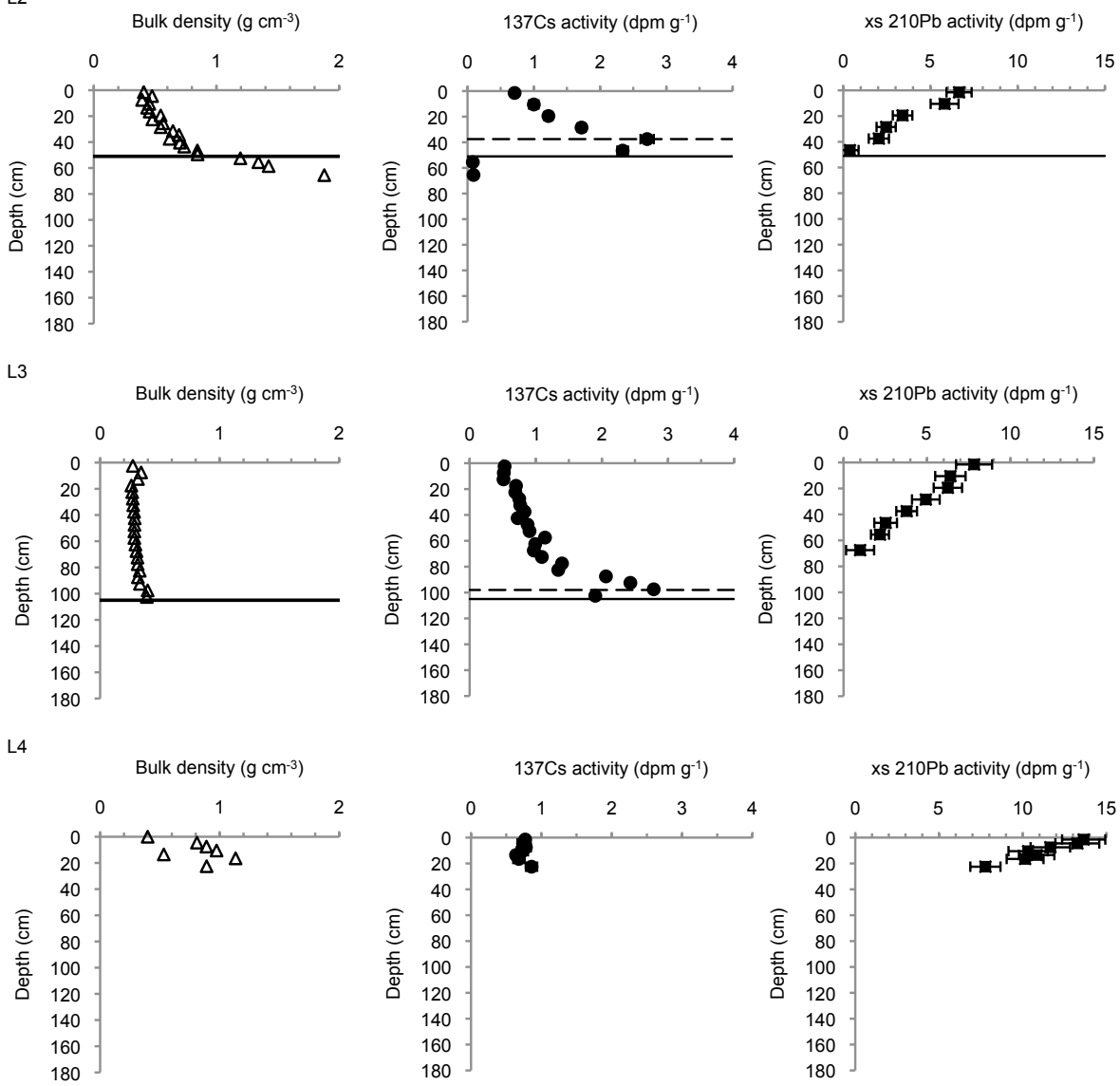

Figure 6. Sediment core profiles of bulk density and radioisotope activities from the eight reservoirs. Solid horizontal lines indicate the pre-impoundment surface (no line indicates the core did not capture the pre-impoundment surface). Dashed lines in ${ }^{137} \mathrm{Cs}$ graphs represent the depth of peak activity. The ${ }^{210} \mathrm{~Pb}$ profile for $\mathrm{L} 3$ is from a second core collected at the same location.

insight to other research showing that woody plants in this region are shallow rooted and do not rely on deeper, perennial water sources (Heilman, 2009; Schwartz et al., 2013; Schwinning, 2008).

It is still not understood why base flow showed a proportional increase 1924-1980. In some landscapes, improving range conditions have led to increased infiltration (Wilcox and Huang, 2010). However, local livestock numbers have remained high, and karst features are limited - unlike other regions where base flow increases have been attributed to rangeland recovery. It is possible that infiltration from local impoundments has added to base flows. Despite mini- mal effects on total streamflow, even small dams can create localized groundwater recharge (Graf, 1999; Smith et al., 2002), and Lampasas River tributaries are characterized by a high degree of connectivity between surface water and local aquifers (Mills and Rawson, 1965).

Perennial flow in this part of the Lampasas River is maintained by isolated springs fed by an aquifer extending beyond the basin (Mills and Rawson, 1965). As a result, the effective catchment of the river is larger than it appears, and spring flow contributions complicate the interpretation of streamflows. At the same time, it is clear that the fundamental relationship between rainfall and streamflow has not changed 

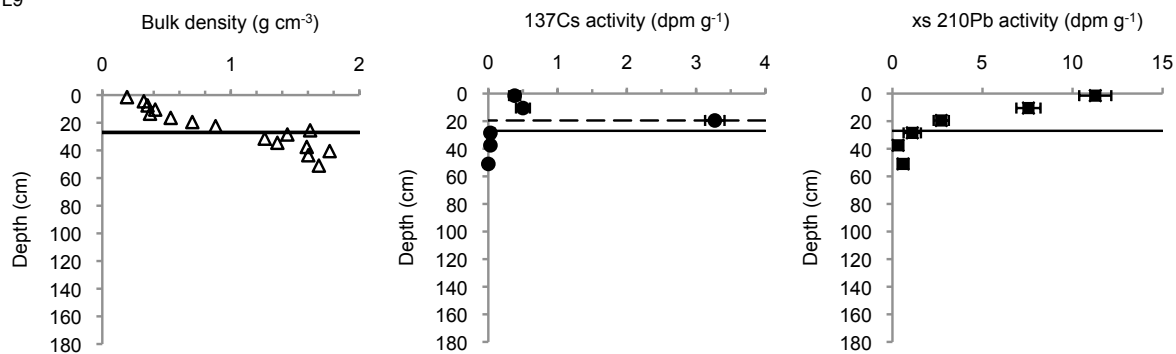

LX

Bulk density $\left(\mathrm{g} \mathrm{cm}^{-3}\right)$
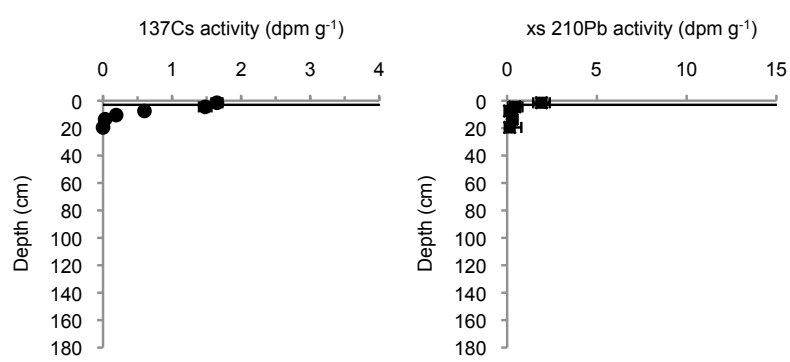

M1

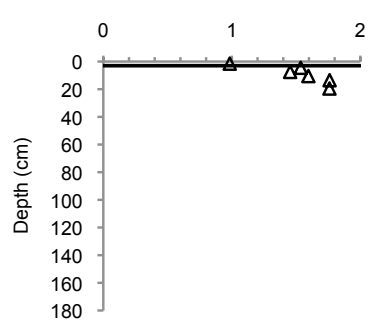

Bulk density $\left(\mathrm{g} \mathrm{cm}^{-3}\right)$
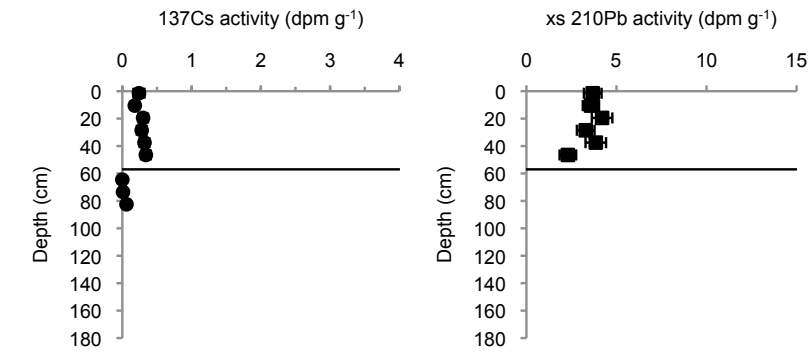

M4
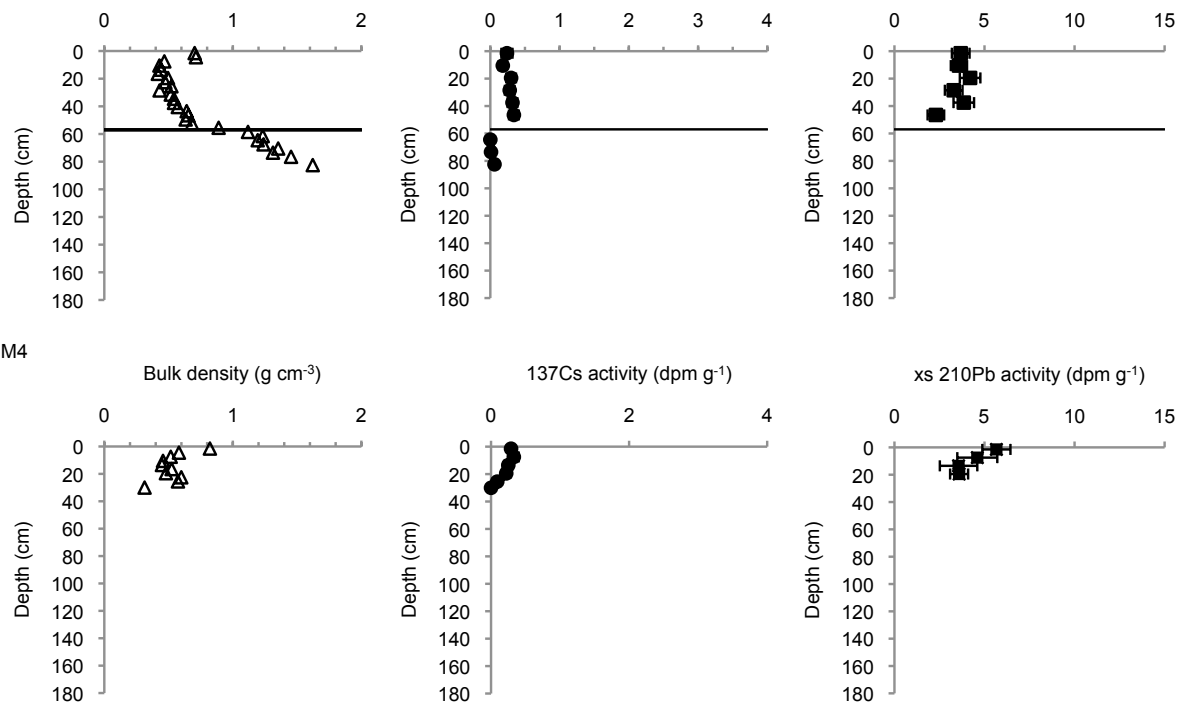

Figure 6. Continued.

over more than 85 years - suggesting that the Lampasas River is hydrologically resilient in the face of changing land use and land cover.

\subsection{Reservoir sedimentation rates}

Because sediment deposition affects reservoir storage and flood detention, understanding sedimentation rates over time is critical to managing rangeland water resources. Though questions do remain regarding the opposing trend in reservoir L3, changes in rates make it clear that sedimentation was more rapid before 1963 . The period since that time has been characterized by stable and lower yields. What explains the higher rates seen during the earlier period? Additional historical landscape data may offer a key interpretive lens.

Livestock can be powerful instruments of landscape change, both directly (trampling soils) and indirectly (disturbing protective vegetation). When grazing is prolonged or intense, sediment yield can be great (Trimble and Mendel, 1995). The high animal densities in this area around the time of reservoir impoundment doubtlessly contributed to erosion (Fig. 3a).

Crop production also can result in accelerated erosion by damaging soil structure and depleting organic matter (Quine et al., 1999). Cropland is a major source of sediment in many landscapes (Foster and Lees, 1999; Blake et al., 2012). In 


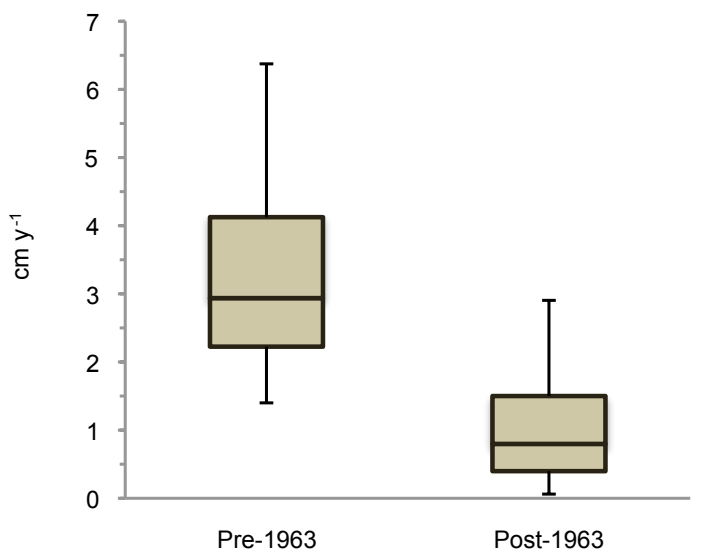

Figure 7. Linear sedimentation rates derived from ${ }^{137} \mathrm{Cs}$ activities. Summary comparison of pre-1963 and post-1963 rates.

our study area, cropland acreage has declined dramatically since the 1930s (Fig. 3b). Further, nationwide improvements in soil conservation have reduced sediment yield from many agricultural lands (Knox, 2001).

While woody plant encroachment influences soil loss, removing undesirable shrubs and trees also elevates short-term sediment yields (Porto et al., 2009). Since the time of initial settlement, woody plant management has resulted in major land cover changes (Fig. 3c). Most early removal was done manually, and the first mechanical control methods were very destructive, leading to high erosion rates (Hamilton and Hanselka, 2004). In recent decades, however, brush removal has declined with shifting landowner priorities (Sorice et al., 2014).

Changes in precipitation frequency, duration, or intensity also affect sediment transport (Xie et al., 2002; Allen et al., 2011). Similarly, drought is an important driver of sediment dynamics in many rangelands. Extended dry periods can cause long-term shifts in plant cover, leading to sediment pulses when rains return (Allen and Breshears, 1998; Nearing et al., 2007). The Lampasas River experienced very high flows in 1957, 1960, 1965, and 1992, and some of these were associated in time with severe droughts (Fig. 8). Just before the impoundment of most of the reservoirs we examined, the region was in the grip of drought conditions unmatched since European settlement (Bradley and Malstaff, 2004). Our sediment records cover only the end of this drought but show pre-1963 deposition 220-630\% faster than subsequent rates. However, any direct effects of the 1957 drought-breaking floods would not be found in the sediments of the reservoirs, which were impounded beginning in 1958. Interestingly, we also did not find spikes in sedimentation associated with high flows or droughts later in the study period. The apparent low importance of drought and floods in sediment delivery in these watersheds is surprising.
Together, these factors have acted over multiple temporal and spatial scales to influence sediment yields in the study area. Yet because there is no clear link between contemporary land use, land cover, and sedimentation rates, it is possible that another process has reduced sediment yields.

\subsection{Sediment storage}

To truly understand the local sediment processes at work, it is important to understand what our findings actually show. Sedimentation rates are poor indicators of in-field soil erosion and redistribution (Nearing et al., 2000; Ritchie et al., 2009); what they do reflect is more closely related to net watershed sediment yield. Sediment yield is buffered by internal storage. Especially at larger scales, watersheds can have a great deal of internal storage, so that very little eroded soil actually leaves the watershed, even in the presence of extreme erosion (Bennett et al., 2005; Porto et al., 2011).

In this study area, the increasing density of farm ponds (Fig. 3d) represents a key potential sink for watershed sediments. These ponds - usually $<0.3$ ha when full - retain material that otherwise would be transported downstream, reducing sediment yields. Because of their smaller contributing watersheds, ponds have high trap efficiencies, magnifying their effects (Brainard and Fairchild, 2012). Indeed, impoundments may be the single greatest anthropogenic modifier of sediment transport; globally, most sedimentation now takes place in aquatic settings and will be retained therein for long periods (Renwick et al., 2005; Verstraeten et al., 2006).

In addition to this storage of eroded sediments in local ponds, a vast amount of sediment from past erosion likely remains on the landscape (Beach, 1994; Meade, 1982). The initial decades after European settlement in this area saw intensive cultivation and very high livestock densities (JordanBychkov et al., 1984; Wilcox et al., 2012a). This destructive combination remained in place for nearly a century in the Lampasas Cut Plain. By the 1930s, many rangelands were already seriously degraded (Mitchell, 2000; Bentley, 1898; Box, 1967). While the methods we used do not allow us to determine whether reservoir sediments result from contemporary erosion or are a legacy of earlier land use, stabilizing sediment yields and observations of local gully erosion suggest that deposits from prior erosion continue to be a source of sediment (Bartley et al., 2007; Mukundan et al., 2011; Phillips, 2003).

The lack of sediments in LX appears to lend support to the importance of internal deposits. This reservoir's watershed is comparable in size to those of L2, L3, and M4, yet sedimentation rates were only $3-14 \%$ of those in the other reservoirs. When L1, L2, and L3 were impounded, the effective catchment area of LX decreased by $86 \%$. Without the historical streamflows and sediment loads from those tributaries, deposits are no longer mobilized and transported downstream.

Given this complexity, we suggest that radioisotope tracers have great potential to elucidate the dynamics of range- 


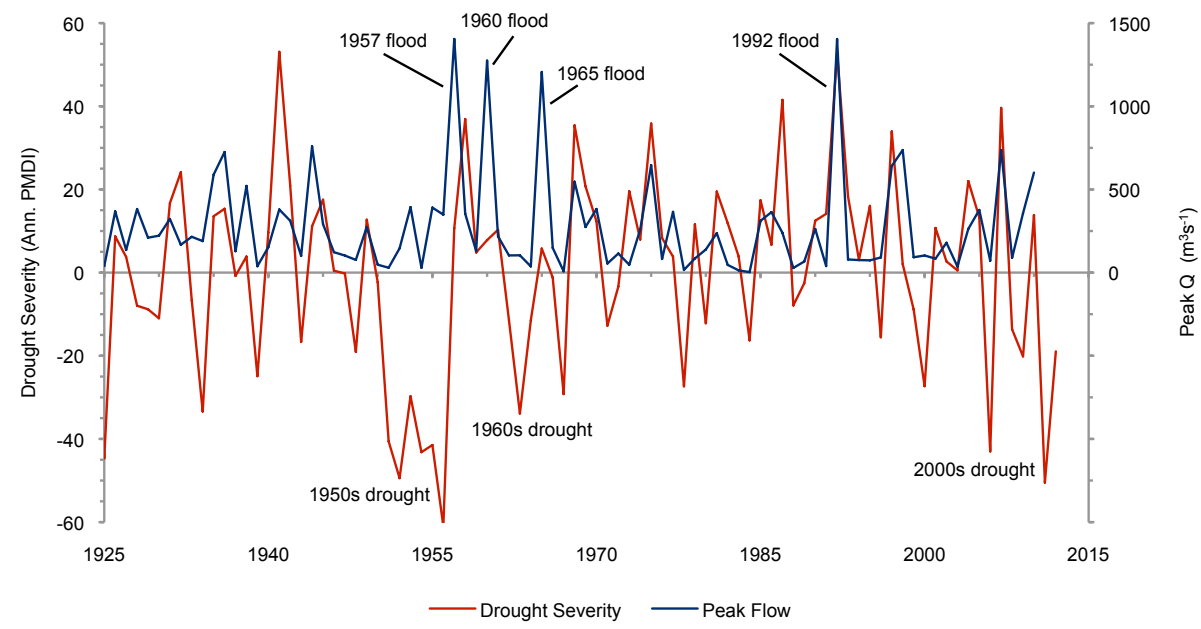

Figure 8. Chronology of regional drought (annual Palmer Modified Drought Index) and peak flows on the Lampasas River.

land systems, particularly as their use evolves from primarily research applications to use as a management and decisionsupport tool (Mukundan et al., 2012). Further strides can be made in understanding rangeland processes by (1) incorporating historical climate, land use, and land cover information to interpret sediment data (Venteris et al., 2004; Boardman, 2006) and (2) including sediment surveys of the farm ponds that are much smaller yet far more abundant than the reservoirs we examined (Downing et al., 2006).

\section{Conclusion}

We examined long-term trends in rainfall, runoff, and sediment yield in rangeland watersheds with a dynamic land use history. Over more than 85 years, neither precipitation nor streamflow showed any directional trend, suggesting a lack of hydrological sensitivity to landscape change. This raises doubts over efforts to increase runoff by directing land cover changes. Reservoir sedimentation rates generally were higher before 1963, and then stabilized at a lower level over the 50 years since 1963 . We believe that this decline in sediment yield is related to long-term landscape changes and an increase in internal storage. As a result, future changes in land use or sediment storage may impact downstream reservoir capacity. These findings challenge simplistic assumptions about streamflow and sediment yield in dynamic rangelands. Determining the role of these landscapes in meeting growing water resource demands requires a creative approach. Integrating multiple techniques with historical information enables a more complete understanding of rangeland processes and holds the key to informed water planning.

\section{Data availability}

Streamflow data are available at the USGS National Water Information System. Stream gages: 08103800 (Kempner) and 08104000 (Youngsport). Drought data are available at the NOAA National Climate Data Center. Texas Climate Division: CD 3 (North Central) and CD 6 (Edwards Plateau).

Acknowledgements. Dan Duncan, Andrea Hanna, and Diana di Leonardo performed activity counts of sediment samples. This work was supported by USDA-NIFA Managed Ecosystems grant 2011-68002-30015, USDA-NIFA National Needs Program grant 2009-38420-05631, NSF-CNH grant 413900, and a Tom Slick Graduate Research Fellowship from the Texas A\&M University College of Agriculture and Life Sciences.

Edited by: L. Wang

\section{References}

Afinowicz, J. D., Munster, C. L., and Wilcox, B. P.: Modeling effects of brush management on the rangeland water budget: Edwards Plateau, Texas, J. Am. Water Resour. Assoc., 41, 181-193, doi:10.1111/j.1752-1688.2005.tb03727.x, 2005.

Allen, C. D. and Breshears, D. D.: Drought-induced shift of a forest-woodland ecotone: Rapid landscape response to climate variation, P. Natl. Acad. Sci. USA, 95, 14839-14842, doi:10.1073/pnas.95.25.14839, 1998.

Allen, P. M., Harmel, R. D., Dunbar, J. A., and Arnold, J. G.: Upland contribution of sediment and runoff during extreme drought: A study of the 1947-1956 drought in the Blackland Prairie, Texas, J. Hydrol., 407, 1-11, doi:10.1016/j.jhydrol.2011.04.039, 2011.

Allison, J. E.: Soil Survey of Lampasas County, Texas, US Department of Agriculture Soil Conservation Service, Washington, D.C., 1991.

Andreadis, K. M. and Lettenmaier, D. P.: Trends in 20th century drought over the continental United States, Geophys. Res. Lett., 33, L10403, doi:10.1029/2006g1025711, 2006. 
Appleby, P. G. and Oldfield, F.: The calculation of lead-210 dates assuming a constant rate of supply of unsupported $210 \mathrm{~Pb}$ to the sediment, Catena, 5, 1-8, doi:10.1016/s0341-8162(78)80002-2, 1978.

Arnold, J. G. and Allen, P. M.: Automated methods for estimating baseflow and ground water recharge from streamflow records, J. Am. Water Resour. Assoc., 35, 411-424, doi:10.1111/j.17521688.1999.tb03599.x, 1999.

Arnold, J. G., Allen, P. M., Muttiah, R., and Bernhardt, G.: Automated base flow separation and recession analysis techniques, Groundwater, 33, 1010, doi:10.1111/j.17456584.1995.tb00046.x, 1995.

Bartley, R., Hawdon, A., Post, D. A., and Roth, C. H.: A sediment budget for a grazed semi-arid catchment in the Burdekin basin, Australia, Geomorphology, 87, 302-321, doi:10.1016/j.geomorph.2006.10.001, 2007.

Beach, T.: The fate of eroded soil - sediment sinks and sediment budgets of agrarian landscapes in southern Minnesota, 18511988, Ann. Assoc. Am. Geogr., 84, 5-28, doi:10.1111/j.14678306.1994.tb01726.x, 1994.

Bennett, S. J., Cooper, C. M., Ritchie, J. C., Dunbar, J. A., Allen, P. M., Caldwell, L. W., and McGee, T. M.: Assessing sedimentation issues within aging flood control reservoirs in Oklahoma, J. Am. Water Resour. Assoc., 38, 1307-1322, 2002.

Bennett, S. J., Rhoton, F. E., and Dunbar, J. A.: Texture, spatial distribution, and rate of reservoir sedimentation within a highly erosive, cultivated watershed: Grenada Lake, Mississippi, Water Resour. Res., 41, W01005, doi:10.1029/2004wr003645, 2005.

Bentley, H. L.: Cattle ranges of the Southwest: a history of the exhaustion of the pasturage and suggestions for its restoration, edited by: United States Department of Agriculture Government Printing Office, Washington, D.C., 32 pp., 1898.

Berg, M. D., Popescu, S. C., Wilcox, B. P., Angerer, J. P., Rhodes, E. C., McAlister, J., and Fox, W. E.: Small farm ponds: overlooked features with important impacts on watershed sediment transport, JAWRA J. Am. Water Resour. Assoc., 52, 67-76, doi:10.1111/1752-1688.12369, 2015a.

Berg, M. D., Sorice, M. G., Wilcox, B. P., Angerer, J. P., Rhodes, E. C., and Fox, W. E.: Demographic Changes Drive Woody Plant Cover Trends - An Example from the Great Plains, Rangel. Ecol. Manag., 68, 315-321, doi:10.1016/j.rama.2015.05.004, 2015b.

Berg, M. D., Wilcox, B. P., Angerer, J. P., Rhodes, E. C., and Fox, W. E.: Deciphering rangeland transformation - Complex dynamics obscure interpretations of woody plant encroachment, Landscape Ecol., in review, 2016.

Bierman, P. R., Albrecht, A., Bothner, M. H., Brown, E. T., Bullen, T. D., Gray, L. B., and Turpin, L.: Erosion, weathering, and sedimentation, in: Isotope Tracers in Catchment Hydrology, edited by: Kendall, C. and McDonnell, J. J., Elsevier, Amsterdam, 647678, 1998.

Blake, W. H., Ficken, K. J., Taylor, P., Russell, M. A., and Walling, D. E.: Tracing crop-specific sediment sources in agricultural catchments, Geomorphology, 139, 322-329, doi:10.1016/j.geomorph.2011.10.036, 2012.

Boardman, J.: Soil erosion science: Reflections on the limitations of current approaches, Catena, 68, 73-86, doi:10.1016/j.catena.2006.03.007, 2006.

Box, T. W.: Range deterioration in West Texas, The Southwestern Historical Quarterly, 71, 37-45, doi:10.2307/30237942, 1967.
Bradley, R. G. and Malstaff, G.: Dry periods and drought events of the Edwards Plateau, Texas, Austin, Texas, 201-210, 2004.

Brainard, A. S. and Fairchild, G. W.: Sediment characteristics and accumulation rates in constructed ponds, J. Soil Water Conserv., 67, 425-432, doi:10.2489/jswc.67.5.425, 2012.

Breshears, D. D.: The grassland-forest continuum: trends in ecosystem properties for woody plant mosaics?, Front. Ecol. Environ., 4, 96-104, doi:10.1890/15409295(2006)004[0096:tgctie]2.0.CO;2, 2006.

Clower, D. F.: Soil Survey of Brown and Mills Counties, Texas, US Department of Agriculture Soil Conservation Service, Washington, D.C., 1980.

de Vente, J. and Poesen, J.: Predicting soil erosion and sediment yield at the basin scale: Scale issues and semi-quantitative models, Earth Sci. Rev., 71, 95-125, doi:10.1016/j.earscirev.2005.02.002, 2005.

Downing, J. A., Prairie, Y. T., Cole, J. J., Duarte, C. M., Tranvik, L. J., Striegl, R. G., McDowell, W. H., Kortelainen, P., Caraco, N. F., Melack, J. M., and Middelburg, J. J.: The global abundance and size distribution of lakes, ponds, and impoundments, Limnol. Oceanogr., 51, 2388-2397, doi:10.2307/3841076, 2006.

Dunbar, J. A., Higley, P. D., and Bennett, S. J.: Acoustic Imaging of Sediment Impounded Within USDA-NRCS Flood Control Dams, Wisconsin, US Department of Agriculture, Agricultural Research Service, National Sedimentation Laboratory, Channel and Watershed Processes Research Unit, Oxford, Mississippi, Research Report No. 30, 2002.

Dunbar, J. A., Allen, P. M., and Bennett, S. J.: Effect of multiyear drought on upland sediment yield and subsequent impacts on flood control reservoir storage, Water Resour. Res., 46, W05526, doi:10.1029/2008wr007519, 2010.

Edwards, K. J. and Whittington, G.: Lake sediments, erosion and landscape change during the Holocene in Britain and Ireland, Catena, 42, 143-173, doi:10.1016/s0341-8162(00)001363, 2001.

Farley, K. A., Jobbágy, E. G., and Jackson, R. B.: Effects of afforestation on water yield: a global synthesis with implications for policy, Global Change Biol., 11, 1565-1576, doi:10.1111/j.1365-2486.2005.01011.x, 2005.

Foley, J. A., DeFries, R., Asner, G. P., Barford, C., Bonan, G., Carpenter, S. R., Chapin, F. S., Coe, M. T., Daily, G. C., Gibbs, H. K., Helkowski, J. H., Holloway, T., Howard, E. A., Kucharik, C. J., Monfreda, C., Patz, J. A., Prentice, I. C., Ramankutty, N., and Snyder, P. K.: Global Consequences of Land Use, Science, 309, 570-574, doi:10.1126/science.1111772, 2005.

Foster, I. D. L. and Lees, J. A.: Changing headwater suspended sediment yields in the LOIS catchments over the last century: a paleolimnological approach, Hydrol. Process., 13, 11371153, doi:10.1002/(sici)1099-1085(199905)13:7<1137::aidhyp794>3.3.CO;2-d, 1999.

Gaspar, L., Navas, A., Walling, D. E., Machin, J., and Arozamena, J. G.: Using Cs-137 and Pb-210(ex) assess soil redistribution on slopes at different temporal scales, Catena, 102, 46-54, doi:10.1016/j.catena.2011.01.004, 2013.

Graf, W. L.: Dam nation: A geographic census of American dams and their large-scale hydrologic impacts, Water Resour. Res., 35, 1305-1311, doi:10.1029/1999wr900016, 1999. 
Griffin, R. C. and McCarl, B. A.: Brushland management for increased water yield in Texas, J. Am. Water Resour. Assoc., 25, 175-186, doi:10.1111/j.1752-1688.1989.tb05679.x, 1989.

Hamilton, W. T. and Hanselka, C. W.: Mechanical practices prior to 1975, in: Brush Management, edited by: Hamilton, W. T., McGinty, A., Ueckert, D. N., Hanselka, C. W., and Lee, M. R., Texas A \& M University Press, College Station, Texas, 17-32, 2004.

Hanna, A. J. M., Allison, M. A., Bianchi, T. S., Marcantonio, F., and Goff, J. A.: Late Holocene sedimentation in a high Arctic coastal setting: Simpson Lagoon and Colville Delta, Alaska, Cont. Shelf Res., 74, 11-24, doi:10.1016/j.csr.2013.11.026, 2014.

Havstad, K. M., Peters, D. P. C., Skaggs, R., Brown, J., Bestelmeyer, B., Fredrickson, E., Herrick, J., and Wright, J.: Ecological services to and from rangelands of the United States, Ecol. Econ., 64, 261-268, doi:10.1016/j.ecolecon.2007.08.005, 2007.

Heilman, J. L., McInnes, K. J., Kjelgaard, J. F., Owens, M. K., and Schwinning, S.: Energy balance and water use in a subtropical karst woodland on the Edwards Plateau, Texas, J. Hydrol., 373, 426-435, 2009.

Huxman, T. E., Wilcox, B. P., Breshears, D. D., Scott, R. L., Snyder, K. A., Small, E. A., Hultine, K., Pockman, W. T., and Jackson, R. B.: Ecohydrological implications of woody plant encroachment, Ecology, 86, 308-319, doi:10.1890/03-0583, 2005.

IAEA: Collection and preparation of bottom sediment samples for analysis of radionuclides and trace elements, International Atomic Energy Agency (IAEA), Vienna, Austria, IAEATECDOC-1360, 2003.

Jackson, R. B., Carpenter, S. R., Dahm, C. N., McKnight, D. M., Naiman, R. J., Postel, S. L., and Running, S. W.: Water in a changing world, Ecol. Appl., 11, 1027-1045, doi:10.2307/3061010, 2001.

Jordan-Bychkov, T. G., Bean, J. L., and Holmes, W. M.: Texas, a Geography, Geographies of the United States, Westview Press, Boulder, Colorado, 288 pp., 1984.

Kim, J. H. and Jackson, R. B.: A Global Analysis of Groundwater Recharge for Vegetation, Climate, and Soils, Vadose Zone J., 11, doi:10.2136/vzj2011.0021RA, 2012.

Knox, J. C.: Agricultural influence on landscape sensitivity in the Upper Mississippi River Valley, Catena, 42, 193-224, doi:10.1016/s0341-8162(00)00138-7, 2001.

Krishnaswamy, S., Lal, D., Martin, J. M., and Meybeck, M.: Geochronology of lake sediments, Earth Planet. Sc. Lett., 11, 407-414, doi:10.1016/0012-821X(71)90202-0, 1971.

Kuhn, T. J., Tate, K. W., Cao, D., and George, M. R.: Juniper removal may not increase overall Klamath River Basin water yields, Calif. Agr., 61, 166-171, 2007.

Lanesky, D. E., Logan, B. W., Brown, R. G., and Hine, A. C.: A new approach to portable vibracoring underwater and on land, J. Sediment. Res., 49, 654-657, 1979.

Lettenmaier, D. P., Wood, E. F., and Wallis, J. R.: HydroClimatological Trends in the Continental United States, 1948-88, J. Clim., 7, 586-607, doi:10.1175/15200442(1994)007<0586:hctitc>2.0.CO;2, 1994.

Lins, H. F. and Slack, J. R.: Streamflow trends in the United States, Geophys. Res. Lett., 26, 227-230, doi:10.1029/1998g1900291, 1999.
Meade, R. H.: Sources, Sinks, and Storage of River Sediment in the Atlantic Drainage of the United States, J. Geol., 90, 235-252, doi:10.2307/30066396, 1982.

Mills, W. B. and Rawson, J.: Base Flow Studies: Lampasas River, Texas, prepared by the U.S. Geological Survey in cooperation with the Texas Water Commission, Austin, Texas, 16 pp., 1965.

Mitchell, J. E.: Rangeland resource trends in the United States, in: General Technical Report RMRS-GTR-68, edited by: Agriculture, USDA, Forest Service, Rocky Mountain Research Station, Fort Collins, Colorado, 1-69, 2000.

Mukundan, R., Radcliffe, D. E., and Ritchie, J. C.: Channel stability and sediment source assessment in streams draining a Piedmont watershed in Georgia, USA, Hydrol. Process., 25, 1243-1253, doi:10.1002/hyp.7890, 2011.

Mukundan, R., Walling, D. E., Gellis, A. C., Slattery, M. C., and Radcliffe, D. E.: Sediment source fingerprinting: Transforming from a research tool to a management tool, J. Am. Water Resour. Assoc., 48, 1241-1257, doi:10.1111/j.1752-1688.2012.00685.x, 2012.

Nearing, M. A., Romkens, M. J. M., Norton, L. D., Stott, D. E., Rhoton, F. E., Laflen, J. M., Flanagan, D. C., Alonso, C. V., Binger, R. L., Dabney, S. M., Doering, O. C., Huang, C. H., McGregor, K. C., and Simon, A.: Measurements and models of soil loss rates, Science, 290, 1300-1301, doi:10.1126/science.290.5495.1300b, 2000.

Nearing, M. A., Nichols, M. H., Stone, J. J., Renard, K. G., and Simanton, J. R.: Sediment yields from unit-source semiarid watersheds at Walnut Gulch, Water Resour. Res., 43, W06426, doi:10.1029/2006wr005692, 2007.

Newman, B., Wilcox, B., Archer, S., Breshears, D., Dahm, C., Duffy, C., McDowell, N., Phillips, F., Scanlon, B., and Vivoni, E.: Ecohydrology of water-limited environments: A scientific vision, Water Resour. Res., 42, W06302, doi:10.1029/2005WR004141, 2006.

Peel, M. C.: Hydrology: catchment vegetation and runoff, Prog. Phys. Geogr., 33, 837-844, doi:10.1177/0309133309350122, 2009.

Petersen, S. L. and Stringham, T. K.: Infiltration, Runoff, and Sediment Yield in Response to Western Juniper Encroachment in Southeast Oregon, Rangel. Ecol. Manag., 61, 74-81, doi:10.2111/07-070R.1, 2008.

Phillips, J.: Alluvial storage and the long-term stability of sediment yields, Basin Res., 15, 153-163, doi:10.1046/j.13652117.2003.00204.x, 2003.

Porto, P., Walling, D. E., and Callegari, G.: Investigating the effects of afforestation on soil erosion and sediment mobilisation in two small catchments in Southern Italy, Catena, 79, 181-188, doi:10.1016/j.catena.2009.01.007, 2009.

Porto, P., Walling, D. E., and Callegari, G.: Using Cs-137 measurements to establish catchment sediment budgets and explore scale effects, Hydrol. Process., 25, 886-900, doi:10.1002/hyp.7874, 2011.

Prcin, L. J., Srinivasan, R., and Casebolt, P.: Lampasas River Watershed Protection Plan, The Lampasas River Watershed Partnership, 207 pp., 2013.

Quine, T. A., Walling, D. E., Chakela, Q. K., Mandiringana, O. T., and Zhang, X.: Rates and patterns of tillage and water erosion on terraces and contour strips: evidence from caesium-137 measure- 
ments, Catena, 36, 115-142, doi:10.1016/s0341-8162(99)00006$5,1999$.

Renwick, W. H., Smith, S. V., Bartley, J. D., and Buddemeier, R. W.: The role of impoundments in the sediment budget of the conterminous United States, Geomorphology, 71, 99-111, doi:10.1016/j.geomorph.2004.01.010, 2005.

Ritchie, J. and McHenry, J. R.: Application of Radioactive Fallout Cesium-137 for Measuring Soil Erosion and Sediment Accumulation Rates and Patterns: A Review, J. Environ. Qual., 19, 215233, doi:10.2134/jeq1990.00472425001900020006x, 1990.

Ritchie, J. C., McHenry, J. R., and Gill, A. C.: Dating Recent Reservoir Sediments, Limnol. Oceanogr., 18, 254-263, doi:10.4319/lo.1973.18.2.0254, 1973.

Ritchie, J. C., Nearing, M. A., Nichols, M. H., and Ritchie, C. A.: Patterns of soil erosion and redeposition on Lucky Hills Watershed, Walnut Gulch experimental watershed, Arizona, Catena, 61, 122-130, doi:10.1016/j.catena.2005.03.012, 2005.

Ritchie, J. C., Nearing, M. A., and Rhoton, F. E.: Sediment budgets and source determinations using fallout Cesium-137 in a semiarid rangeland watershed, Arizona, USA, J. Environ. Radioact., 100, 637-643, doi:10.1016/j.jenvrad.2009.05.008, 2009.

Sanchez-Cabeza, J. A. and Ruiz-Fernández, A. C.: ${ }^{210} \mathrm{~Pb}$ sediment radiochronology: An integrated formulation and classification of dating models, Geochim. Cosmochim. Ac., 82, 183-200, doi:10.1016/j.gca.2010.12.024, 2012.

Schwartz, B. F., Schwinning, S., Gerard, B., Kukowski, K. R., Stinson, C. L., and Dammeyer, H. C.: Using hydrogeochemical and ecohydrologic responses to understand epikarst process in semiarid systems, Edwards Plateau, Texas, USA, Acta Carsologica, 42, 315-325, 2013.

Schwinning, S.: The water relations of two evergreen tree species in a karst savanna, Oecologia, 158, 373-383, doi:10.1007/s00442008-1147-2, 2008.

Smith, S. V., Renwick, W. H., Bartley, J. D., and Buddemeier, R. W.: Distribution and significance of small, artificial water bodies across the United States landscape, Sci. Total Environ., 299, 2136, doi:10.1016/s0048-9697(02)00222-x, 2002.

Sorice, M. G., Kreuter, U. P., Wilcox, B. P., and Fox III, W. E.: Changing landowners, changing ecosystem? Land-ownership motivations as drivers of land management practices, J. Environ. Manage., 133, 144-152, doi:10.1016/j.jenvman.2013.11.029, 2014.

Tanner, B. M.: A study of the feasbility of water power development at proposed flood control dams on the Leon and Lampasas Rivers, Master of Science, Civil Engineering, Agricultural and Mechanical College of Texas, College Station, Texas, 57 pp., 1937.

Texas State Soil and Water Conservation Board: State Brush Control Plan, Temple, Texas, 53 pp., 2005.

Tilman, D., Cassman, K. G., Matson, P. A., Naylor, R., and Polasky, S.: Agricultural sustainability and intensive production practices, Nature, 418, 671-677, doi:10.1038/nature01014, 2002.

Trimble, S. W. and Mendel, A. C.: The cow as a geomorphic agent - a critical review, Geomorphology, 13, 233-253, doi:10.1016/0169-555x(95)00028-4, 1995.

US Army Corps of Engineers: Sedimentation Investigations of Rivers and Reservoirs, in: Engineering and Design, US Army Corps of Engineers, Washington, D.C., 1989.
US Army Corps of Engineers: Hydrographic Surveying, in: Engineering and Design, US Army Corps of Engineers, Washington, D.C., Engineering Manual 1110-2-1003, 2013.

USDA-NRCS: Conservation practice standard: brush management practice code 314, edited by: USDA-NRCS, US Department of Agriculture, NRCS, Washington, D.C., 4 pp., 2006.

Van Auken, O. W.: Shrub invasions of North American semiarid grasslands, Annu. Rev. Ecol. Syst., 31, 197-215, doi:10.1146/annurev.ecolsys.31.1.197, 2000.

Venteris, E. R., McCarty, G. W., Ritchie, J. C., and Gish, T.: Influence of management history and landscape variables on soil organic carbon and soil redistribution, Soil Sci., 169, 787-795, doi:10.1097/01.ss.0000148742.75369.55, 2004.

Verstraeten, G., Bazzoffi, P., Lajczak, A., Rãdoane, M., Rey, F., Poesen, J., and de Vente, J.: Reservoir and pond sedimentation in Europe, in: Soil Erosion in Europe, John Wiley \& Sons, Ltd, 757-774, 2006.

Vorosmarty, C. J. and Sahagian, D.: Anthropogenic disturbance of the terrestrial water cycle, Bioscience, 50, 753-765, doi:10.1641/0006-3568(2000)050[0753:adottw]2.0.CO;2, 2000.

Walling, D. E., Collins, A. L., and Sichingabula, H. M.: Using unsupported lead-210 measurements to investigate soil erosion and sediment delivery in a small Zambian catchment, Geomorphology, 52, 193-213, doi:10.1016/s0169-555x(02)00244-1, 2003.

Wilcox, B. P.: Shrub control and streamflow on rangelands: a process based viewpoint, J. Range Manage., 55, 318-326, 2002.

Wilcox, B. P. and Huang, Y.: Woody plant encroachment paradox: Rivers rebound as degraded grasslands convert to woodlands, Geophys. Res. Lett., 37, L07402, doi:10.1029/2009g1041929, 2010.

Wilcox, B. P. and Thurow, T. L.: Emerging issues in rangeland ecohydrology - Preface, Hydrol. Process., 20, 3155-3157, doi:10.1002/hyp.6324, 2006.

Wilcox, B. P., Breshears, D. D., and Allen, C. D.: Ecohydrology of a resource-conserving semiarid woodland: effects of scale and disturbance, Ecol. Monogr., 73, 223-239, doi:10.1890/00129615(2003)073[0223:EOARSW]2.0.CO;2, 2003.

Wilcox, B. P., Dowhower, S. L., Teague, W. R., and Thurow, T. L.: Long-Term Water Balance in a Semiarid Shrubland, Rangeland Ecol. Manag., 59, 600-606, doi:10.2111/06-014R3.1, 2006.

Wilcox, B. P., Sorice, M. G., Angerer, J., and Wright, C. L.: Historical changes in stocking densities on Texas rangelands, Rangeland Ecol. Manag., 65, 313-317, doi:10.2111/rem-d-11-00119.1, 2012a.

Wilcox, B. P., Turnbull, L., Young, M. H., Williams, C. J., Ravi, S., Seyfried, M. S., Bowling, D. R., Scott, R. L., Germino, M. J., Caldwell, T. G., and Wainwright, J.: Invasion of shrublands by exotic grasses: ecohydrological consequences in cold versus warm deserts, Ecohydrology, 5, 160-173, doi:10.1002/eco.247, 2012 b.

Winter, L. T., Foster, I. D. L., Charlesworth, S. M., and Lees, J. A.: Floodplain lakes as sinks for sediment-associated contaminants - a new source of proxy hydrological data?, Sci. Total Environ., 266, 187-194, doi:10.1016/s0048-9697(00)00745-2, 2001.

Xie, Y., Liu, B., and Nearing, M. A.: Practical thresholds for separating erosive and non-erosive storms, Trans. ASAE, 45, 18431847, 2002. 